\title{
PERAN VIDEO BLOG SEBAGAI MEDIA PEMBELAJARAN DALAM MENINGKATKAN HASIL BELAJAR BAHASA INGGRIS
}

\author{
Agyztia Premana ${ }^{1}$, Ubaedillah ${ }^{2}$, Damar Isti Pratiwi ${ }^{3}$ \\ ${ }^{1,2}$ Universitas Muhadi Setiabudi, ${ }^{3}$ Politeknik Perkeretaapian Indonesia \\ 1..premana@umus.ac.id, 2ubaedillah2@gmail.com, 31amar@ppi.ac.id
}

\begin{abstract}
Abstrak: Video blog adalah satu video berisi mengenai opini, cerita atau kegiatan harian yangbiasanya dibuat tertulis pada blog, bahkan video blog pada awalnya menjadi sarana untukmengekspresikan diri dan pendapat kepada publik. Namun, lama-kelamaan, hasil yangada akhirnya, beberapa Vlogger mengekspresikan dirinya terlalu 'bebas' dan cenderungsecara 'negatif' sehingga muncul tren seperti penggunaan kata kasar atau makian dalamvideo dan tren gaya hidup berbudaya barat yang bebas. Maraknya Video blog di media sosialmenjadi tontonan rutin para anak muda
\end{abstract}

Kata Kunci: media pembelajaran, video blog, bahasa inggris.

Abstract: A video blog is a video that includes thoughts, stories, or everyday events that are usually published on a blog; video blogs, too, started as a way for people to express themselves and their opinions to the public. However, as a result of this, some Vloggers become too 'free' and 'negative,' resulting in phenomena like the use of harsh words or curses in videos and the trend of a free Western cultured lifestyle. For young people, the emergence of video blogs on social media has become a daily viewing experience.

Keywords: learning media, video blog, english language.

\section{PENDAHULUAN}

Perkembangan ilmu pengetahuan dan teknologi (IPTEK) merupakan salah satu produksi dari manusia yang terdidik, dan pada gilirannya manusia-manusia itu perlu lebih mendalami dan mampu mengambil manfaat dan bukan menjadi korban dari IPTEK. Mendalami serta mengambil manfaat dari perkembangan IPTEK tidak mungkin dilakukan oleh semua manusia dengan kadarwaktu yang sama. Keterbatasan manusia dan waktu menuntut adanya spesialisasi yang semakin mendalam(J. K. Pendidikan, 2018).

Media pembelajaran menghadapi dua tantangan, tantangan yang pertama muncul dari perubahan persepsi tentang belajar itu sendiri dan tantangan yang kedua dari teknologi informasi dan komunikasi yang memperlihatkan perkembangan yang luar biasa. Konstruktivisme pada dasarnya telah menjawab tantangan yang pertama dengan meredefinisi belajar sebagai proses konstruktif yaitu informasi diubah menjadi pengetahuan melalui proses interpretasi, korespondensi, representasi, dan elaborasi. Sementara itu, kemajuan teknologi informasi dan komunikasi yang begitu pesat yang menawarkan berbagai kemudahankemudahan baru dalam pembelajaran memungkinkan terjadinya pergeseran orientasi belajar pada masyarakat. Teknologi memiliki peran penting dalam memperbarui konsepsi pembenaran yang semula fokus pada pembelajaran yang semata-mata suatu penyajian berbagai pengetahuan menjadi pembelajaran sebagai suatu bimbingan agar mampu melakukan eksplorasi sosial-budaya yang kaya akan pengetahuan(An et al., 2019).

Tetapi pada kenyataannya, pemanfaatan teknologi belum sepenuhnya terealisasi dalam proses pembelajaran.Beberapa Guru belum mampu memanfaatkan teknologi dalam kegiatan pembelajaran di ruang kelas. Hal ini mengakibatkan penyajian materi pembelajaran masih memanfaatkan kondisi selama ini yang terjadi di lingkungan sekolah. Guru hanya memanfaatkan papan tulis sebagai fasilitas dalam proses penyajian bahan ajar.

Ada dua hal yang mengakibatkan para guru belum memanfaatkan teknologi dalam proses pembelajaran di ruang kelas. Permasalahan yang pertama adalah banyak guru tidak mengetahui samasekali dalam menggunakan perangkat teknologi, seperti computer atau samrtphone yang saat ini banyak diimplementasikan dalam segala bidang(J. T. Pendidikan, 2019).

Menurut Sadiman dalam Fitriyani mengatakan pada penelitian bahwa "pemilihan media pembelajaran harus disesuaikan dengantujuan dan materi pembelajaran,karakteristik siswa, 
jenis rangsangan yangdiinginkan, lingkungan, kondisi setempat,dan jangkauan media itu sendiri. Hal ini berkaitan dengan kondisi pembelajaran bahasa inggris diIndonesia yang cenderung membosankanbai sebagian siswa. observasi yangtelah dilakukan oleh Surtati dan Ikamengatakan bahwa kebosanan ini sesungguhnya bukan hanya disebabkan oleh materinya yang cenderung teoritis,Anak Usia Dini mengatakan bahwa"dengan menggunakan media video blog,lebih mudah bagi guru untuk menjelaskankepada anak usia dini mengenai karakteryang baik" (Mata, Sistem, \& Di, 2020).

Permasalahan kedua yang sering muncul berkenaan dengan penggunaan mediapembelajaran, yakni ketersediaan dan pemanfaatan. Ketersediaan media masih sangat kurang sehingga para guru menggunakan media secara minimal. Media yang sering digunakan adalah media cetak (diktat, modul, hand out, buku teks, majalah, surat kabar, dan sebagainya), dan didukung dengan alat bantu sederhana yang masih tetap digunakan seperti papan tulis/white board dan kapur/spidol. Sedangkan media audio dan visual (kaset audio, siaran televisi/radio, overhead transpa-rency, video/film,), dan media elektronik (komputer, internet) masih belum secara intensif dimanfaatkan(Hasil \& Siswa, 2018). Media cetak merupa-kan media yang paling sering digunakan oleh pengajar, karena mudah untuk dikembangkan maupun dicari dari berbagai sumber. Kenyataan yang sering terlihat adalah, banyak guru menggunakan media pembelajaran seadanya tanpa pertimbangan pembelajaran.

Penyajian materi ajar di ruang kelas hanya dengan memanfaatkan fasilitas yang sangat sederhana mengakibatkan siswa tidak berminat dalam proses belajar. Selain itu, kemampuan belajar siswa tidak meningkat karena siswa tidak dibiasakan untuk aktif dalam belajar. Siswa menjadi pasif karena penyajian bahan ajar hanya menggunakan papan tulis yang secara langsung mengakibatkan aktivitas siswa hanya mencatat bahan yang diberikan. Dalam hal tersebut mengakibatkan siswa menjadi pasif. Kegiatan pembelajaran seperti ini sangat bertolak belakang dengan pendidikan karakter yang mengharuskan peserta didik memiliki karakter, salah satunya ialah aktif dalam pembelajaran.

Untuk menghasilkan siswa yang aktif, seorang guru tidak hanya harus profesional dari segi keilmuan tapi juga harus profesional dari segi pedagogik. Guru yang tidak profesional dari segi pedagogik, tidak mampu merancang pemilihan fasilitas dalam penyajian bahan ajar. Seperti yang telah diutarakan diawal, ini terjadi karena ketidaksiapan guru dalam menghadapi era globalisasi dalam inovasi hasil teknologi.

Salah satu fasilitas teknologi yang sangat menarik untuk dimanfaatkan dalam pembelajaran adalah media youtube vlog. Youtube vlog adalah bentuk video aplikasi berbasis web berbentuk tulisan-tulisan yang dimuat sebagai posting pada sebuah halaman web youtube. Tulisan-tulisan ini seringkali dimuat dalam urut terbalik (isi terbaru dahulu baru kemudian diikuti isi yang lebih lama), meskipun tidak selamanya demikian (Pembelajaran, 2020).

Video Blog salah satu layanan aplikasi dari internet dapat dimanfaatkan oleh guru dan siswa sebagai sumber belajar yang tidak terbatas. Guru dapat mengisi semua informasi yang berkaitan dengan materi pembelajaran yang diajarkan. Dilihat dari pihak lain, siswa dapat mengunduh informasi yang sesuai dengan topik dan tujuan yang diinginkan. Penggunaan youtube vlog sebagai sebagai media pembelajaran sekaligus sebagai sumber belajar sedikitnya akan mengubah cara belajar dan teknik pembelajaran agar tidak monoton sehingga dapat memotivasi siswa dalam mempelajari sesuatu(Pada, Jarak, \& Covid-19, 2020).

\section{Belajar Dan Hasil Belajar Bahasa Inggris}

Belajar dalam pengertian yang luas adalah guru dan siswa mengetahui pokok-pokok yang penting dari aspek-aspek perbuatan belajar. Para ahli psikologi berbeda-beda dalam menerangkan cara-cara perbuatan belajar itu berlangsung. Akan tetapi dari penemuanpenemuan dan percobaan telah memperlihatkan bahwa belajar yang sukses selalu diikuti oleh kemajuan yang tertentu yang terbentuk dari pola berpikir dan berbuat. Apabila hal itu yang dimaksud, maka perbuatan belajar adalah untuk memperoleh sukses dalam pengembangan potensi-potensi individu berkat dilakukannya perbuatan belajar terhadapnya.

"Blog is a forumfor anyone who wants to express opinion,or share information personally orsocially. Blogs can be used for writing andVlog can be used for communication"(Yunanto et al., 2019). berpendapat bahwa belajar adalah perbuatan untuk memperoleh kebiasaan, ilmu pengetahuan dan berbagai sikap. Hal itu termasuk penemuan 
cara-cara baru dalam mengerjakan sesuatu dan hal itu terjadi pada usaha-usaha individu dalam memecahkan rintangan-rintangan atau untuk penyesuaian terhadap tiap situasi yang baru.

$$
\text { Media pembelajaran senantiasa }
$$
melakukan perubahan tingkah laku atau penampilan, dengan serangkaian kegiatan misalnya dengan membaca, mengamati, mendengarkan, meniru dan lain sebagainya. Belajar itu akan lebih baik, kalau si subjek belajar itu mengalami atau melakukannya, jadi tidak bersifat verbalistik. Tujuan belajar secara umum adalah untuk mendapatkan pe-ngetahuan (kognitif), keterampilan (psiko-motorik) dan pemahaman sikap mental/nilai-nilai (afektif). Pencapaian tujuan belajar berarti akan menghasilkan hasil belajar.

Dalam belajar bahasa, orang mengenal keterampilan reseptif dan keterampilan produktif. Keterampilan reseptif meliputi keterampilan menyimak (listening) dan keterampilan membaca (reading), sedangkan keterampilan produktif meliputi keterampilan berbicara (speaking) dan keterampilan menulis (writing). Baik keterampilan reseptif maupun keterampilan produktif perlu dikembangkan dalam proses pembelajaran bahasa Inggris(Pemanfaatan Alat Peraga Edukatif Sebagai Media Pembelajaran Bahasa Inggris Sekolah Dasar, 2017).

Keterampilan listening adalah untuk membiasakan siswa untuk mendengarkan berbagai aksen pengucapan bahasa Inggris dari berbagai negara sehingga siswa mampu berkomunikasi dalam bahasa Inggris dengan berbagai aksen yang digunakan oleh lawan bicara. Keterampilan reading berfokus pada kemampuan siswa untuk memahami sebuah teks dalam bahasa Inggris untuk segala keperluan. Kemampuan membaca teks bahasa Inggris dapat dilakukan melalui skim dan scan teks yang dibaca.

Keterampilan writing diukur dengancara siswa mampu menyusun struktur kalimat maupun teks sesuai dengan tata bahasa dan struktur kalimat. Keterampilan speaking dinilai dengan kemampuan siswa dalam berkomunikasi dalam bahasa Inggris dengan pengucapan dan intonasi yang benar sehingga lawan bicara memahami yang diucapkan.

\section{Media Pembelajaran}

Secara harfiah media berarti perantara atau pengantar.media pembelajaran adalah seluruh alat dan bahan yang dapat dipakai untuk tujuan pendidikan, seperti radio, televisi, buku, koran, majalah dan sebagainya. Rossi dan Breidl menambahkan alat-alat semacam radio dan televisi kalau digunakan dan diprogram untuk pendidikan, maka merupakan media pembelajaran. media apabila dipahami secara garis besar adalah manusia, materi atau kejadian yang membangun kondisi yang membuat siswa mampu memperoleh pengetahuan, keterampilan atau sikap. Dalam pengertian ini, guru, buku teks dan lingkungan sekolah merupakan media. Secara lebih khusus, pengertian media dalam proses belajar mengajar cenderung diartikan sebagai alat-alat grafis, photografis atau elektronis untuk menangkap, memproses dan menyusun kembali informasi visual atau verbal.

Media pembelajaran tersebut sebagai segala sesuatu yang dapat digunakan untuk merangsang fikiran, perasaan, perhatian dan kemauan siswa sehingga dapat mendorong terjadinya proses belajar pada diri siswa. Romiszowski (1988: 8) berpendapat media as the carriers of messages, from some transmitting source (which may be a human being or an inanimate object) to the receiver of messages (which in our case is the learner.

Menurut Suryani (2020) media adalah bentuk maupun fungsinya yang sudah dirancang sehingga bisa digunakan untuk memperlancar kegiatan proses belajar pada pihak sasaran. Media juga berfungsi mengandung dan bahkan memperjelas ide-ide atau gagasan-gagasan yang disampaikan oleh komunikator dalam kegiatannya.

Media adalah suatu istilah yang menunjukkan segala sesuatu yang membawa informasi antara sumber dan penerima. Selanjutnya media disebut sebagai media pembelajaran disebabkan oleh pengaplikasian media tersebut dalam proses belajar dan mengajar. Mendefinisikan video blog media pembelajaran sebagai fasilitas yang digunakan untuk komunikasi dan belajar.

Dari beberapa batasan tentang media yang dikemukakanmenunjukkan bahwa pengertian media pada intinya berkisar pada alat penyalur atau pembawa pesan, dan tidak terbatas pada masalah instruksional atau jenis kegiatan belajar mengajar lainnya. Bahkan suatu alat, asalkan mampu berfungsi sebagai pembawa pesan atau informasi dari satu orang kepada orang lain, bisa dianggap sebagai media.

Media sebagai alat saluran dalam proses pembelajaran memiliki berbagai macam karakteristik. pengelompokkan media ke dalam 
media suara, media visual, dan media gerak. Pada perkembangan selanjutnya media tersebut bisa bergabung menjadi satu kesatuan, artinya tidak terpisah-pisah seperti halnya media visual, media suara atau media gerak(Pemanfaatan Alat Peraga Edukatif Sebagai Media Pembelajaran Bahasa Inggris Sekolah Dasar, 2017).klasifikasi media menjadi empat karakteristik, yaitu:

1. media grafis (visual diam): gambar/foto, diagram, bagan, poster dan grafik,

2. media proyeksi,

3. media audio, dan

4. media komputer: penggunaan multimedia presentasi, Compact Disk (CD) mutimedia interaktif dan pemanfaatan internetan.

Pembagian jenis media tersebut dapat dimanfaatkan untuk proses instruksional. Perannya banyak, diantaranya untuk visualisasi ide atau gagasan komunikator. Di samping itu, dapat juga dijadikan alat untuk merangsang sasaran agar termotivasi pada hal-hal yang sedang dibicarakan. Yang tidak kalah pentingnya adalah media dapat mempertinggi daya serap belajar pada pihak sasaran serta dapat menghindari verbalisme yang berlebihan.

Media pembelajaran secara umum mempunyai kegunaan untuk mengatasi hambatan dalam berkomunikasi, keterbatasan fisik dalam kelas, sikap pasif anak didik serta mempersatukan pengamatan anak. Penggunaan media pembelajaran secara tepat dan bervariasi dapat mengatasi sikap pasif anak didik(Hasil \& Siswa, 2018). Dalam hal ini media pembelajaran berguna untuk:

1. Menimbulkan kegairahan belajar,

2. Memungkinkan interaksi yang lebih langsung antara anak didik dengan lingkungan dan kenyataan, dan

3. Memungkinkan belajar sendiri-sendiri, menurut kemampuan dan minat anak didik.

Dalam pemilihan media pembelajaran sebagai alat untuk mengatasi hambatan dalam berkomunikasi, keterbatasan fisik dalam kelas, sikap pasif anak didik serta mempersatukan pengamatan anak haruslah mempertimbangkan kriteria dalam pemilihannya. petunjuk-petunjuk umum yang dipakai di dalam pemilihan media, yaitu:

1. Pilih media yang sesuai dengan tingkat kedewasaan, minat dan kemampuan siswa. Media yang terlalu sederhana atau kekanakkanakan akan membosankan bagi kelompok siswa usia dewasa atau mereka yang berpengalaman luas,
2. Pilih media yang paling sesuai dengan aktivitas belajar yang akan dilakukan siswa, usahakan adanya keseimbangan dalam macam media yang dipilih, artinya hindari pemakaian satu macam media saja,

3. Pilih media yang merupakan komplemen suatu sumber belajar, bukan mengulang apa yang telah disajikan sumber belajar tadi. Misalnya memakai slides atau gambar untuk mempelajari mesin yang dapat dilihat di bengkel.

4. Hindari pemakaian media yang berlebih dan juga dipilih hanya karena media tersebut telah tersedia. kriteria utama pemilihan media seharusnya adalah pemakaian media tersebut mampu meningkatkan proses belajar siswa dan pemakaian media memang diperlukan.

Beberapa pendapat para ahli yang telah dikemukakan dapat disimpulkan bahwa pemakaian media dalam proses belajar haruslah benar-benar dilaksanakan dengan memperhatikan beberapa karakter yang dapat mendukung media tersebut sebagai alat bantu dalam proses komunikasi dalam proses belajar dan mengajar. Adapun karakter yang harus diperhatikan dalam pemilihan media pembelajaran antara lain harus sesuai dengan metode pembelajaran, materi pembelajaran, karakteristik siswa. Selain itu media pembelajaran harus menarik dan mampu memudahkan mahasiswa dalam belajar(Malang, 1998).

\section{Pembelajaran Video Blog}

Video Blog merupakan bentuk aplikasi web yang menyerupai tulisan-tulisan (yang dimuat sebagai posting) pada sebuah halaman web umum. Tulisan-tulisan ini seringkali dimuat dalam urut terbalik (isi terbaru dahulu baru kemudian diikuti isi yang lebih lama), meskipun tidak selamanya demikian. Situs web seperti ini biasanya dapat diakses oleh semua pengguna internet sesuai dengan topik dan tujuan dari si pengguna blog tersebut.

Berdasarkan hasil survei online (17 - 23 September 2015) tentang mata kuliah multimedia pembelajaran memperoleh mata kuliah tersebut, ditemukan data $68,4 \%$ mahasiswa mengalami kesulitan dalam mengembangkan multimedia pembelajaran, dan $78,9 \%$ mahasiswa menyatakan sumber belajar yang tersedia selama perkuliahan kurang memadai. 
Secara garis besar, video blog dapat dirangkum sebagai kumpulan website pribadi yang memungkinkan para pembuatnya menampilkan berbagai jenis isi pada web dengan mudah, seperti karya tulis, kumpulan link internet, dokumen-dokumen (file-file word, PDF, dll), gambar ataupun multimedia. Video disini dapatmenggambarkan suatu objek yangbergerak bersama-sama dengan

Suara alamiah atau suara yang sesuai sehinggasiswa tidak hanya melihat gambar saja, melainkan dapat melihat dan mendengar secara bersama-sama media yang digunakan oleh guru selama pembelajaran(Mata et al., 2020).

Youtube vlog adalah sebuah situs web dimana postingan itemnya dilakukan secara teratur dan ditampilkan dalam urutan kronologis mundur. Istilah blog sebenarnya adalah versi pendek/bentuk singkat dari youtube vlog atau video log. Penulis/pemilik blog yang merawat dan menambahkan artikel baru ke dalam blog miliknya disebut blogging. Pengiriman artikel satu-persatu disebut posting blog (blog post), post, atau entries. Orang yang mengirimkan artikel atau orang yang memiliki blog disebut blogger. Sebuah blog terdiri dari teks, hypertext, gambar, dan beberapa link (ke halaman web lain, video, audio, dan file-file lain). Youtube vlog menggunakan gaya bahasa penyampaian dokumentasi. Seringkali youtube vlog lebih fokus ke salah satu topik, misalnya tips trik, tutorial, ponsel, dan lain sebagainya. Beberapa youtube vlog juga menceritakan pengalamanpengalaman pribadi mereka.

\section{Media Pembelajaran Youtube vlog Dalam Proses Belajar Mengajar}

Pemanfaatan youtube vlog sebagai media pembelajaran memiliki banyak keuntungan, terutama dari segi efektifitas dan efisiensi. Dari segi efektifitas, siswa akan menjadi aktif dalam belajar karena materi pelajaran tidak diberikan secara langsung oleh guru tersebut di ruang kelas, tetapi materi yang akan diberikan telah di upload ke youtube vlogguru. Dengan demikian siswa harus aktif menngunduh materi tersebut agar dapat mengikuti materi yang akan diberikan. Sedangkan dari segi efisiensi, pemanfaatan youtube vlog sebagai media pembelajaran dapat memanfaatkan alokasi waktu dalam proses pembelajaran untuk kegiatan lain karenaalokasi waktu untuk menjelaskan materi pelajaran telah tergantikan dengan siswa mengunduh materi dari youtube vlog(Sugiono, 2019).
Pemanfaatan youtube vlog sebagai media pembelajaran bahasa Inggris dapat dilakukan dengan cara:

1. Membuat post sebagai media diskusi,

2. Membuat halaman sebagai tempat menampilkan suatu mata pelajaran, dan

3. Membuat sub halaman sebagai tempat menampilkan suatu pokok bahasan dalam suatu mata pelajaran.

4. Keunggulan media pembelajaran youtube vlogseperti yang dituliskan oleh suryana adalah:

5. Dapat diakses oleh para siswa kapan saja dan di mana saja,

6. Dapat dibangun dengan mudah tidak memerlukan bahasa pemrograman khusus, dan

7. Dapat dibangun gratis tanpa biaya sepeserpun.

Penggunaan youtube video blog didalam pendidikan atau pembelajaran masuk pada kategori Web Centric Course. Web Centric Course merupakan pembelajaran dimana sebagian bahan belajar, diskusi, konsultasi, penugasan dan latihan disampaikan melalui internet, sedangkan ujian dan sebagian konsultasi, diskusi dan latihan dilakukan secara tatap muka. Walaupun dalam proses belajarnya sebagian dilakukan dengan tatap muka yang biasanya berupa tutorial, tetapi presentase tatap muka lebih kecil dibandingkan dengan presentase-presentase belajar melalui internet(Era, Informasi, \& Perancangannya, 2019).

Dalam pembelajaran dengan media youtube vlog, guru mengisi materi-materi pelajaran yang akan disampaikan kepada siswa kedalam youtube vlog pribadinya. Siswa dapat mengunduh materi tersebut jauh hari sebelum pertemuan. Dengan begitu, siswa dapat mempelajari materi tersebut dirumah. Penjelasan pada tatap muka dikelas diganti oleh siswa dengan menjelaskan kembali materi yang telah diunduh. Siswa diefektifkan mempelajari materi yang telah diunduh. Proses belajar akan menjadi efektif karena siswa ditantang untuk belajar aktif. Artinya, siswa harus giat dalam mencari materi yang akan dipelajarinya dengan membuka youtube vlog. Guru juga bersikap aktif dengan mempersiapkan materi yang akan diisi ke youtube vlog pribadinya. Guru bertindak sebagai fasilitator dengan cara menyediakan materi yang akan dipelajari oleh mahasiswa. 


\section{METODE PENELITIAN}

Penelitian ini akan dilaksanakan pada kampus Universitas Muhadi Setibudi, pada penelitian ini diawali dengan melakukan peninjauan ke lokasi penelitian untuk mengetahui secara cermat.Teknik analisa data yang digunakan dalam penuliasn jurnal adalah analisa content.

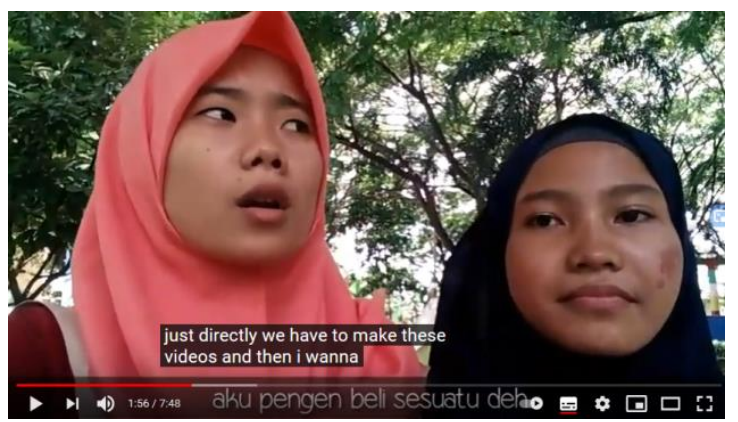

Gambar 1. Belajar berbicara bahasa inggris

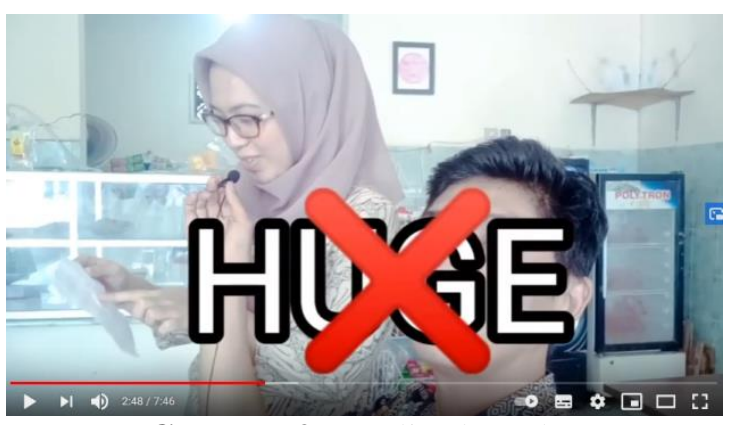

Gambar 2. Analisa baca kata

(Courtesy Of YouTube Ubaedillah UMUS)

Sampel populasi penelitian berdasarkan asumsi bahwa mahasiswa tersebut memiliki karakteristik yang relatif sama, misalnya: memiliki rata-rata umur yang relatif sama, menggunakan fasilitas pembelajaran yang relatif sama, serta dibelajarkan oleh guru yang memiliki latar belakang pendidikan yang relatif sama. Pemilihan mahasiswa sebagai sampel dalam penelitian memungkinkan dengan alasan mahasiswa saat ini sudah mampu menguasai IPTEK. Mereka dapat mendownload materi pembelajaran dari handphone (HP) mereka. Selain itu mahasiswa sudah mampu menguasai internet karena standar kompetensi untuk pelajaran TIK (teknologi informasi komunikasi) memuat tentang internet.

\section{HASIL DAN PEMBAHASAN}

Pada tahap analisis kebutuhan atau dapat disebut tahap define the scope dan identify learner characteristic yang ada pada tahap perencanaan (planning), dilakukan survei online yang telah diisi oleh 30 responden. Untuk mengetahui jenis media seperti apa yang dibutuhkan oleh siswa, pada butir terakhir isntrumen analisis kebutuhan, responden dapat memilih satu dari 4 alternatif pilihan media, sehingga diperoleh hasil 17 mahasiswa (89\%) memilih format media terpadu yang terdiri dari 3 jenis media (buku, video, dan simulasi) dan 2 mahasiswa lainnya (11\%) memilih jenis media berbasis simulasi yang ditunjukkan dalam diagram Gambar 3.
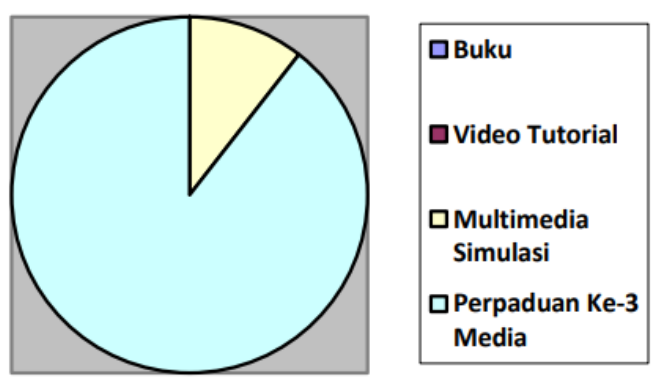

Gambar 3. Media yang dipilih

Berdasarkan observasi yang dilkaukan pada penlitian yang dianggap membosankan bagi mahasiswa, bahkan pelaksanaan kegiatan mengajar hanya untuk menghafal informasi yang disampaikan oleh dosen.

Untuk menilai tingkat kebermanfaatan produk Video Blog interaktif dalam meningkatkan hasil belajar kognitif mahasiswa, digunakan instrumen tes dan lembar praktik unjuk kerja. Instrumen tes merupakan tes latihan/kuis yang ada dalam babVideo Blog interaktif. Saat dilaksanakan uji coba kelompok besar, mahasiswa memilih untuk materi yang dipelajari bersama yakni tentangPrinsip-Prinsip dalam Pengembangan Multimedia Pembelajaran Interaktif sertaPraktik Mandiri Pengembangan Multimedia Pembelajaran Interaktif. Pada awalpembelajaran, mahasiswa diminta mengerjakan 10 butir soal latihan, sedangkan pada akhir pertermuan mahasiswa melakukan praktik unjuk kerja sesuai dengan tahap-tahap latihan yang ada pada Video Blog interaktif.

Hasil dari pembelajaran video blog bahasa inggris dapat menjadikan mahasiswa lebih fokus pada materi yang diinginkan karena ada kaitan dengan teknologi editing sehingga mahasiswa dapat menggunakan vlog tersebut lebih kreatif, inovatif dan animatif. Untuk mendukung hal tersebut, maka dalam aspekpenyusunan koncten dengan materi 
didukung menggunakan teori urutan kegiatan belajar yang dikemukakan oleh Ubeadillah:

"The vlogs utilization was capable of establishing students' social skills since the vlogs could improve cooperation and social interaction between the students as well as compliance with school regulation (Karamina, 2020).

Penerapan Video Blog interaktif ini dinilai mampu menignkatkan aspek kreatif dimulai reading, listening dan speaking sehinga mahasiswa dapat memotivasi selama proses belajar bahasa inggris bahkan vlog lebih efektif dibandingkan dengan media konvensional.

\section{SIMPULAN}

Media pembelajaran video blog (vlog) menjadi salah satu solusi dalam kegiatan belajar dalam era pandemi saat ini. Hal tersebut menjadi faktor karena generasi sekarang sudah tidak asing lagi dalam menggunakan perangkat lunak, bgitu juga vlog dapa bermanfaat bagi siswa atau kalangan maysarakat seacara mudah dimengerti karena dalam vlog terdapat gimik yang menarik, backsound, penyampaian materi bahasa inggris sehingga tumbuh rasa percaya diri dalam belajar bahasa inggris, bahkan menjadi acuan prestasi belajar lebih giat lagi.

Pelaksanaan pembelajaran menggunakan media vlog dapat dimanfaatkan bagi mahasiswa dalam memahami materi pembelajaran reading, lestening dan speaking, sehingga dapat menghasil pengingkatan dalam paham bahasa inggris. Mahasiswa dengan nilai kreatifitas tinggi cenderung memiliki prestasi belajar yang lebih menonjol dibandingkan mahasiswa pasif.

Gunakan dan manfaatkan media dengan baik dan benar karena penggunaan media dalam pembelajaran sangat membantu dalam pembelajaran dan mengrekonstruksi motivasi mahasiswa dalam belajar agar semangat dalam proses pembelajaran karena penggunaan media dalam pembelajaran sangat interaktif dan tidak monoton sehingga peserta didik (mahasiswa) tidak cenderung bosan dalam pembelajaran.

\section{DAFTAR PUSTAKA}

An, D., Learning, I., Application, M., To, N., The, E., Sense, N., \& Android, B. Y. U. (2019). Perancangan Aplikasi Media Pembelajaran Pengenalan Pahlawan Nasional untuk Meningkatkan Rasa Nasionalis Berbasis Android. 09(02), 113120.
Era, S., Informasi, T., \& Perancangannya, D. A. N. (2019). Media Pembelajaran.

Hasil, M., \& Siswa, B. (2018). Kata Kunci : Media Pembelajaran dan Hasil Belajar Siswa. 03, 171-187.

Malang, U. N. (1998). Penerapan Pemilihan Media Pembelajaran Zainul Abidin. 9-20.

Mata, P., Sistem, P., \& Di, K. (2020). PENGEMBANGAN Media Pembelajaran Interaktif. 8(1).

Pada, P. E., Jarak, P., \& Covid-, M. P. (2020). Biblio couns. 3(2), 41-49.

Pemanfaatan Alat Peraga Edukatif Sebagai Media Pembelajaran Bahasa Inggris Sekolah Dasar. (2017). 19-24.

Pembelajaran, M. (2020). Transformasi Media Pembelajaran Pada Masa Pandemi Covid19. 1, 82-93.

Pendidikan, J. K. (2018). Peranan Media Pembelajaran Dalam Meningkatkan The Role Of Instructional Media To Improving. 2(2).

Pendidikan, J. T. (2019). No Title. 12(1), 62-74.

Sugiono, S. (2019). Vlog Sebagai Media Storytelling Digital Bagi Tokoh Publik Pemerintahan Vlog As Government Public Figure 'S Media For Digital. 115-134.

Yunanto, A. A., Herumurti, D., Rochimah, S., Kuswardayan, I., Yunanto, A. A., Herumurti, D., ... Kuswardayan, I. (2019). ScienceDirect ScienceDirect ScienceDirect English Education Game using Non-Player Character Based on English Education Game using Non-Player Character Based on Natural Language Processing Natural Language Processing. Procedia Computer Science, 161, 502-508. https://doi.org/10.1016/j.procs.2019.11.15 8 